\title{
KETERTARIKAN PENGUSAHA MUSLIM PAMELLA SUNARDI PEMILIK PAMELLA SUPERMARKET YOGYAKARTA MENGGUNAKAN PRODUK PEMBIAYAAN DI BANK SYARIAH
}

\author{
Trimulato \\ Dosen Perbankan Syariah Universitas Muhammadiyah Parepare \\ Email: trimsiuii@yahoo.co.id
}

\begin{abstract}
Islamic banking now has a legal strength by the presence of law number 21 of 2008 which is very influential for the existence of Islamic banking. Currently the market share of Islamic banking has reached 5 percent of the total national banking. Islamic banking products continue to grow over time; the funds of third-party in the period of June 2016 reached $12,185,860$ trillion rupiah with financing funds of 3,027,266 trillion rupiah. This suggests that the existence of inequality especially on financing products of Islamic banks must be optimized byofferingfinancing products to all people, especially to Muslim entrepreneurs in order that they use the products to develop their business. A Muslim businessman, Sunardi Pamella, the owner of Pamella supermarket Yogyakarta has become a customer of Islamic bank and employs its products to develop her businesses. The demand on financing products of Islamic banks is still low, so that Islamic banks need to promote their products to Muslim entrepreneurs. This paper focuses on financing products of Islamic banks and the motivation of Pamella Sunardi as a businessman to usethe products. This is alibrary research and the results show that the number of loan of Islamic banking has grown 6,074 percent or higher than that ofconventional bank. Further, the number of loan is 10.127 percent in BPRS, but in Islamic business unitsis -8.234 percent. Pamella Sunardi uses financing products offered by Islamic Bank because he wants to do business based on Islamic ethics. Besides, he hasa trauma with conventional banks' products.
\end{abstract}

Keywords:Pamella Sunardi, Financing Products, Islamic Banking.

\begin{abstract}
Abstrak
Perbankan syari'ah saat ini telah memiliki payung hukum yang kuat dengan hadirnya undang-undang nomor 21 tahun 2008 tentang perbankan syari'ah. Hal ini sangat berpengaruh terhadap eksistensi dari perbankan syari'ah yang semakin diminati oleh banyak kalangan.Saat ini pangsa pasar bank syariah telah mencapai 5 persen dari total perbankan secara nasional. Produk perbankan syariah terus mengalami pertumbuhan dari waktu ke waktu, dana pihak ketiga di Bank Syariah pada periode juni 2016 mencapai 12.185.860 triliyun rupiah dan dana pembiayaan 3.027.266 triliyun rupiah. Hal ini menunjukkan adanya ketimpangan khusunya pada produk pembiayaan di bank syariah harus lebih dioptimalkan. Bank syariah bisa menawarkan produk pembiayaan kepada semua kalangan khususnya kepada para pengusaha muslim untuk digunakan sebagi modal pengembangan usaha. Salah satu pengusaha muslim Pamella Sunardi pemilik supermarket Pamella Yogyakarta menjadi nasabah pembiayaan di bank syariah untuk mengembangkan usahanya. Adapun pertumbuhan pembiayaan di bank syariah masih sangat minim dibutuhkan upaya bagi bank syariah agar menawarkan kepada para pengusaha muslim.Batasan dalam tulisan ini difokuskan pada produk pembiayaan di bank syariah serta ketertarikan pengusaha Pamella
\end{abstract}


Sunardi menggunakan produk pembiayaan di bank syariah. Tulisan ini menggunakan studi pustaka kajian dari berbagai sumber. Dalam tulisan ini menggunakan jenis penelitian kualitatif. Hasil dari tulisan ini menunjukkan bahwa jumlah rekening pembiayaan di bank syariah mengalami pertumbuhan 6,074 persen pada bank umum syariah, kemudian 10,127 persen pada BPRS, sedangakan pada unit usaha syariah turun -8,234 persen. Kemudian ketertarikan Pamella Sunardi menggunakan produk pembiayaan di Bank Syariah, pertama menerapkan etika bisnis islam pada usahanya, kedua karena pernah mengalami trauma menggunakan produk bank konvensional.

\section{Kata Kunci : Pamella Sunardi, Produk Pembiayaan, dan Bank Syariah}

\section{Pendahuluan}

Seiring dengan perbaikan dan reformasi perbankan nasional pasca krisis ekonomi, perbankan syari'ah yang merupakan bagian dari perbankan nasional mulai memasuki babak baru implementasi sistem perbankan nasional dengan segala hambatan dan perkembangan yang secara berkala terus diperbaiki sesuai dengan syariat Islam. Perbankan syari'ah era reformasi dimulai dengan disetujuinya Undang-undang No.10 tahun 1998 tentang perbankan syari'ah. ${ }^{1}$ Kemudian disempurnakan dengan adanya undang-undang Perbankan Syari'ah nomor 21 tahun 2008.

Ide dasar sistem perbankan Islam sebenarnya dapat dikemukakan dengan sederhana.Operasi institusi keuangan Islam terutama berdasarkan pada prinsip PLS (porfitand-loss-sharing bagi untung dan rugi). Prinsip bagi hasil ini dalam keuangan Islam sangat dianjurkan dan merupakan solusi yang pantas dan relefan untuk mengatasi masalah alokasi dana yang terbatas, baik yang berupa dana pinjaman atau tabungan dengan maksud supaya pengelolaan dan pembiayaan bisnis secara efektif dapat tercapai. Bank Islam tidak membebankan bunga, melainkan mengajak partisipasi dalam bidang usaha yang didanai.Para deposan juga sama-sama mendapat bagian dari keuntungan bank sesuai dengan rasio yang telah ditetapkan sebelumnya. Dengan demikian ada kemitraan antara bank Islam dan para deposan di satu pihak, dan antara bank para nasabah investasi sebagai pengelola sumber daya para deposan dalam berbagai usaha produktif dipihak lain. ${ }^{2}$

Karakteristik sistem perbankan syariah yang beroperasi berdasarkan prinsip bagi hasil memberikan alternatif sistem perbankan yang saling menguntungkan bagi masyarakat dan bank, serta menonjolkan aspek keadilan dalam bertransaksi, investasi yang beretika, mengedepankan nilai-nilai kebersamaan dan persaudaraan dalam berproduksi, dan

\footnotetext{
${ }^{1}$ Muhammad Syafi'i Antonio, Bank Syariah: Dari Teori ke Praktik.,Jakarta, Gema Insani Press, 2001, hlm. 26

2Latifa M. Algaoud dan Mervyn K. Lewis, Perbankan Syariah, Prinsip, Praktik, Prospek, Jakarta, PT. Serambi Ilmu Semesta, 2001, hlm. 910
}

48 | al-Maslahah - Volume 13 Nomor 1 A pril 2017 
menghindari kegiatan spekulatif dalam bertransaksi keuangan. Dengan menyediakan beragam produk serta layanan jasa perbankan yang beragam dengan skema keuangan yang lebih bervariatif, perbankan syariah menjadi alternatif sistem perbankan yang kredibel dan dapat dinimati oleh seluruh golongan masyarakat Indonesia tanpa terkecuali. ${ }^{3}$

Sebutan bank islam yang kemudian yang lebih dikenal sebagai bank syariah idealnya menjadi unggulan umat islam. Unggulan artinya bank syariah adalah alternatif pertama yang dipilih nasabah dalam memenuhi kebutuhan pembiayaan masyarakat. Itu harapan (want) yang ideal. Perbankan syariah diharapkan dapat memenuhi berbagai jenis kebutuhan (needs) pengguna jasa bank syariah. ${ }^{4}$ Bank syariah perlu memahami bentuk perilatu konsumsi masyarakat. Faktor promosi merupakan salah satu faktor penentu keberhasilan program pemasaran sekaligus untuk menginformasikan kelebihan-kelebihan produk dan membujuk konsumen untuk membelinya. Betapapun berkualitasnya produk/jasa, bila konsumen belum pernah mendengarnya, maka mereka tidak akan pernah membelinya. ${ }^{5}$

Bank syariah tidak bisa lepas dari kegiatan sektor riil, keduanya saling berhubungan satu sama lain dan tidak bisa dilepaskan. Adapun yang dimaksud dengan sektor riil adalah ekonomi yang nyata nampak dan banyak dilakukan masyarakat. Sektor riil bisa meliputi kegiatan jual beli, sewa menyewa, dan kegiatan bisnis yang dapat menumbuhkan perekonomian. Pertumbuhan sektor riil dapat ditumbuhkan melalui adanya bantuan dari sektor keuangan salah satunya adalah melalui bank syariah. Bank syariah sendiri tidak lepas dari sektor riil khususnya dalam menyalurkan produk pembiayaan yang dimilikinya. Produk pembiayaan di bank syariah terdiri dari pembiayaan dengan akad jual beli, pembiayaan dengan akad sewa, dan pembiayaan dengan akad bagi hasil.

Pada sektor riil melekat adanya para pengusaha sebagai penggerak usaha atau bisnis yang mereka miliki. Para pemilik usaha akan selalu ingin mengembangakan usaha yang mereka miliki, biasanya dalam mengembangkan bisnis perlu adanya penambahan modal. Bank syariah bisa menjadi alternatif dalam memberikan modal kepada para pengusaha. Bank syariah harus bisa memperkenalakan diri sebagai mitra yang dapat ikut serta dalam mengembangkan usaha. Di indonesia dengan negara yang mayoritas penduduknya muslim kurang lebih 85 persen. Harusnya bisa difasilitasi oleh bank syariah untuk melengkapi

\footnotetext{
${ }^{3}$ Diakses dari http://www.bi.go.id/web/id/Perbankan/Perbankan+Syariah/ Pada tanggal 18 pebruari 2011

4Syafaruddin Alwi. Memahami Sistem Perbankan Syariah Berkaca Pada Pasar Umar Bin Khattab. 2013. Jakarta: BukuRepublika., hal. 134

5Tjiptono, Fandi .Pemasaran J asa. (Malang: Bayu Media, 2002), hal. 219.
} 
kebutuhan keuangan mereka. Khususnya bagi para pengusaha muslim seharusnya dalam mengembangkan kegiatan bisnisnya dalam hal memenuhi modal harusnya menggunakan bank syariah, apalagi bunga di bank konvensional sudah difatwakan haram oleh majelis ulama indonesia pada tahun 2004.

Salah satu sosok pengusaha muslim yang menggunakan produk pembiayaan bank syariah dalam rangka membuka atau mengembangkan bisnisnya adalah Pamella Sunardi, perempuan sebagi pemilik Pamella supermarket di Yogyakarta. Swalayan yang sangat terkenal itu dan memiliki beberapa cabang di kota yogyakarta. Hidup religius dan banyak memahami agama mengantarkannya untuk lebih memilih bank syariah. Sebelumnya keluarganya pernah menggunakan produk pinjaman atau kredit di bank konvensional. Pengusaha muslim ini menganggap bahwa bank itu jahat yang banyak menguras hasil kerja kerasnya. Dalam sebuah buku pengusaha muslim ini bercerita bahwa uang yang diperoleh dari hasil kerja keras harus disetorkan ke bank, maka kami tak pernah bisa menyisihkan uang untuk membeli pakaian. Kami hanya bisa mendapatkan pakaian baru, kalau dibelikan oleh saudara-saudara kami. Sering juga kami mendapat pakaian bekas yang masih bagus dari saudara-saudara kami. Meski pikiran buruk terhadap bank muncul akibat pikiran anak-anak yang masih naif, namun kesan bahwa bank itu jahat, sempat melekat hingga dewasa dan menjadi semacam trauma bagi saya. Saya enggan bila harus berurusan dengan perbankan.”ungkap Pamella Sunardi. ${ }^{6}$

Lebih lanjut Pamella Sunardi mengungkapkan adanya perasaan trauma terhadap kantor bank masih cukup lama melekat dibenak saya. Saya tidak berani jika harus berhubungan dengan bank. Saat saya dan suami menggeluti usaha ritel Pamella sehingga kemudian berkembang memiliki 7 cabang, tidak sepeser pun kami menggunakan modal dari bank. Baru setelah saya dan suami saya menerjuni bisnis SPBU tahun 2005 lalu, saya mulai mencoba kembali berhubungan dengan bank. Itupun atas dorongan suami. Perbankan yang kami pilih untuk mendapat pinjaman adalah perbankan syariah.” Cerita Pamella Sunardi. ${ }^{7}$

Bank syariah harus lebih intens dalam mengenalkan diri sebagai lembaga yang bisa menjadi pilihan para pengusaha muslim. Memperkenalkan diri sebagai yang bisa menjadi mitra bagi para pengusaha muslim. Khususnya dalam rangka untuk bisa menarik nasabah

\footnotetext{
${ }^{6}$ Eko Widiyanto, Dengan Keluarga Sakinah Membangun Bisnis Barokah. Yogyakarta: Mitra Pustaka Nurani., hal 53-54 7lbid., hal 54
} 
untuk memilih produk di bank syariah. Pada tabel di bawah iniakan disajikan tentang pertumbuhan nasabah di bank syariah.

Tabel 1.1

Jumlah Nasabah Dana Pihak Ketiga dan Nasabah Pembiayaan di Bank Syariah

\begin{tabular}{|c|c|c|c|}
\hline NO & Tipe Nasabah & Juni 2016 & FREKUENSI \\
\hline $\mathbf{1}$ & Dana Pihak Ketiga & 12.185 .860 & $80,11 \%$ \\
\hline $\mathbf{2}$ & Pembiayaan & 3.027 .266 & $19,89 \%$ \\
\hline $\mathbf{3}$ & TOTAL & 15.213 .126 & $100 \%$ \\
\hline
\end{tabular}

Sumber: OJK, Statistik Perbankan Syariah Tahun 2016 (Data diolah)

Dari data diatas menujukkan adanya kondisi jumlah nasabah di bank syariah. Menjelaskan bahwa jumlah nasabah yang menggunakan produk di bank syariah didominasi oleh nasabah dana pihak ketiga sebesar 80,11\% sedangkan nasabah pembiayaan tidak mencapai $20 \%$ hanya pada angka 19,89\%. Yang seharusnya bahwa dana pihak ketiga harusnya tersalurkan ke masyarakat dalam bentuk pembiayaan. Jangan sampai dana nasabah pihak ketiga hanya mengendap atau sekedar disetorkan di bank lain. Perlu ada upaya bagi bank syariah untuk meningkatkan jumlah nasabah atau pangsa pasar untuk produk pembiayaan. Salah satu pangsa pasar yang baik bagi produk pembiayaan bank syariah yaitu adalah pengusaha muslim makin banyak. Jadi pembiayaan di bank syariah tidak hanya berorientasi pada produk pembiayaan untuk konsumsi tetapi juga bisa dalam bentuk pembiayaan modal kerja bagi para pengusaha muslim.

Pembiayaan modal kerja syariah terdiri lima skim pembiayaan yaitu, bentuk mudharabah, istisnha, salam, murabahah dan ijarah. Jenis pembiayaan mana yang dipilih tergantung pada jenis kebutuhan dan jenis usaha nasabah. Nasabah bisa mengajukan salah satu dari lima skim pembiayaan modal kerja syariah diawal. Jika nasabah ingin pembiayaan mudal kerja industri barang-barang konsumsi seperti garmen, sepatu, furniture, dan sebagainya, nasabah dapat mengajukan skim pembiayaanpembiayaan istisnha. Skim ini lebih fleksibel bagi nasabah karena pembiayaan disesuaikan dengan kebutuhan dengan sistem pembayaran sesuai kesepakatan (cicilan atau termin pembayaran). Dalam sistem perbankan syariah, istisnha adalah akad jual beli barang berdasarkan pesanan antara nasabah sebagai pemesan dan pihak bank syariah dengan kriteria tertentu. Bank akan membelikan pesanan 
tersebut dari supplier barang dengan harta dan cara pembayaran yang disepakati bersama dengan nasabah. ${ }^{8}$

Bagi manajemen bank syariah, hal perlu memperoleh perhatian terhadap pembiayaan yang diajukan nasabah antara lain, karakteristik transaksi jenis usaha yang dibiayai, misalnya apakah penjualan, pembelian bahan baku, dilakukan secara tunai. Kemudian skala usaha, tingkat risiko dari jenis usaha yang akan dibiayai dan sifat pasar yang dihadapi. Apakah suatu usaha telah memiliki pelanggan tetap atau usaha berdasarkan pesanan dan sebagainya. Semua faktor-faktor tersebut dalam perspektif bank syariah dianalisis dalam upaya melindungi kepentingan kedua belah pihak dari risiko bisnis yang fatal dan bukan hanya melindungi kepentingan pihak bank syariah. ${ }^{9}$

Dari uraian diatas penulis tertarik untuk melakukan pendalaman mengenai ketertarikan pengusaha muslim Pamella Sunardi Pemilik Pamella Supermarket Yogyakarta menggunakan produk pembiayaan di Bank Syariah.Mengingat saat ini, market share bank syariah baru mencapai target 5 persen. Sehingga dibutuhkan upaya ekstra dari bank syariah untuk mampu memenuhi produknya baik itu produk funding maupun produk finacingnya. Untuk meningkatkan nasabah financing bank syariah tanpa terkecuali kepada para pengusaha muslim, yang hendak mengembangkan usaha atau bisnis yang dimilikinya. Bank syariah harus bisa menarik hati para pengusaha muslim agar hendak membutuhkan modal bisa menggunakan produk pembiayaan di bank syariah, agar bisnis bisa menjadi lebih berkah.

\section{Identifikasi Masalah}

Berdasarkan latar belakang yang telah dipaparkan dan beberapa ulasan yang ada terkait dengan ketertarikan pengusaha muslim Pamella Sunardi pemilik supermarket Pamella Yogyakarta menggunakan produk pembiayaan di bank syariah.Maka dibutuhkan upaya dari bank syariah untuk bisa mengamati dan memahami dari perilaku konsumen para konsumen dan lebih giat memperkenalkan produk pembiayaan bagi para pengusaha muslim yang ada. Hal ini dengan tujuan agar memacu minat para pengusaha muslim yang hendak mengembangkan ushanya dan membutuhkan modal usaha agar memilih produk pembiayaan di lembaga keuangan syari'ah, khususnya di perbankan syari'ah. Terdapat dua permasalahan utama yang masih dihadapi oleh industri perbankan syariah pada produk pembiayaan di bank syariah, antara lain;

${ }^{8}$ Syafaruddin Alwi. Memahami Sistem Perbankan. hal. 138 
1. Produk pembiayaan di bank syariah belum dikenal secara sepenuhnya bagi para pengusaha muslim, sehingga masih banyak pengusaha muslim yang menggunakan jasa perbankan konvensional. Padahal sistem bunga di bank konvensional adalah hal yang diharamkan. Sebagai seorang muslim yang taat para pengusaha muslim harusnya menggunakan produk bank syariah yang sejalan dengan syariah islam. Produk pembiayaan belum dikenal secara maksimal oleh para pengusaha muslim.

2. Produk pembiayaan di bank syari' ah yang hampir menyerupai produk pembiayaan di bank konvensional. Hal ini menjadikan masyarakat khususnya para pengusaha muslim merasa tidak ada perbedaan antara keduanya, membuatnya untuk memilih mana yang lebih mudah untuk diakses dan tidak mempersulitnya. Sehingga dibutuhkan kerja keras bagi bank syariah untuk memperlihatkan karakteristik yang dimilikinya serta keunggulan yang dimilikinya. Agar para pengusaha muslim mau menggunakan produk pembiayaan di bank syariah, disertai pelayanan dan fasilitas yang memadai melebihi bank konvensional.

\section{Rumusan Masalah}

Bagaimana ketertarikan pengusaha muslim Pamella Sunardi sehingga memilih produk pembiayaan di Bank Syariah?

\section{Tujuan Penulisan}

Tujuan dari tulisan ini adalah untuk :

1. Untuk mengetahui perkembangan rekening nasabah pembiayaan di bank syariah.

2. Untuk mengetahui ketertarikan pengusaha muslim Pamella Sunardi pemilik supermarket Pamella Yogyakarta menggunakan produk pembiayaan di bank syariah.

\section{Manfaat Penulisan}

Tulisan ini diharapkan dapat memberikan kontribusi bagi beberapa pihak, memberikan manfaat kepada;

1. Dunia Praktis Perbankan Syari'ah

Tulisan ini diharapkan dapat dengan segera ditindaklanjuti sehinggamampu menjadikan berupa rekomendasi dan bahan masukan bagi manajemen bank syari'ah dalam membuat kebijakan yang berkaitan dengan menumbuhkan minat masyarakat memilih produk pembiayaan di bank syari'ah. 
Tulisan ini diharapkan memberi manfaat berupa perangsang bagi semua pihak di bank syari'ah mau berinovasi dalam lebih giat dalam memperkenalkan produk pembiayaanya kepada masyarakat khususnya bagi para pengusaha muslim agar meningkatkan minat masyarakat dalam memilih produk pembiayaan di bank syariah.

2. Dunia Akademisi

Tulisan ini diharapkan bisa menjadi koleksi khasanah ilmiah dalam rangka peningkatan dan pengembangan produk pembiayaan di bank syari'ah yang juga dikaji di lembaga pendidikan. Serta menerangkan upaya bank syariah dalam memasarkan produk pembiayaan bagi para pengusaha muslim.

3. Umum

Tulisan ini diharapkan menjadi bahan pertimbangan bagi masyarakat khususnya para pengusaha muslim dalam melibatkan diri dalam memilih produk pembiayaan di bank syari'ah.

\section{Telaah Pustaka}

Sebelum melakukan penelitian, peneliti berusaha menelaah literatur karya ilmiah sebelumnya yang berkaitan dengan judul yang diteliti.Hasil penelitian-penelitian yang pernah dilakukan sebelumnya perlu dikemukakan sebagai bahan perbandingan dengan penelitian yang dilakukan penulis. Adapun karya-karya ilmiah yang relevan dengan topik yang peneliti angkat antara lain:

Penelitian Bank Indonesia yang berjudul "Penelitian Potensi, Preferensi, dan Perilaku Masyarakat Terhadap Bank Syariah di Wilayah Jawa Barat'.Secara umum performa bank syariah saat ini masih kalah jauh dibandingkan dengan bank konvesional. Bank syariah lebih diminati kalangan berpenghasilan menengah ke bawah, orang memilih bank karena pertimbangan pelayanan, fasilitas, kredibilitas, dan status bank. ${ }^{10}$

Dalam penelitian Bank Indonesia yang berjudul "Penelitian Potensi, Preferensi dan Perilaku Masyarakat Terhadap Bank Syariah di Wilayah J awa Timur".Faktor-faktor yang mempengaruhi minat masyarakat berhubungan dengan bank syariah dicari dengan analisis regresi. Penelitian di wilayah Malang Variabel independen: agama islam; pengetahuan responden tentang keberadaan bank syariah; pendapat responden tentang bunga bank; tingkat

\footnotetext{
${ }^{10}$ Bank Indonesia, Penelitian Potensi, Preferensi dan Perilaku Masyarakat Terhadap Bank Syariah di Wilayah J awa Barat (Bogor: Lembaga Penelitian IPB,2000).
} 
pendidikan responden; jenis pekerjaan; tingkat pendapatan; preferensi terhadap bank syariah; pengetahuan responden tentang produk dan mekanisme bank syariah. ${ }^{11}$

Yudi Sutarso dalam papernya yang berjudul " Peranan Penggunaan Prinsip Syari'ah dan Budaya dalam Model Kualitas Jasaloyalitas pada Perbankan Syari'ah". Memperoleh hasil penelitian yaitu: pertama, dari tanggapan yang diberikan oleh responden dapat dikatakan bahwa secara umum persepsi pelanggan terhadap perbankan syari'ah adalah cukup positif terhadap berbagai aspek menyangkut kualitas jasa, demikian juga tingkat kepuasan dan loyalitas mereka. Kedua, hipotesis yang menguji dimensi kualitas jasa terhadap kepuasan pelanggan semua terbukti dan mendapat dukungan dalam penelitian ini.Peranan penerapan prinsip syariah dalam perbankan terbukti mempengaruhi kepuasan pelanggan.Ketiga, budaya yang dalam penelitian ini diredusir menjadi sikap terhadap resiko tidak dapat dibuktikan pengaruhnya kepuasan.Keempat, tingkat kepuasan terbukti memiliki pengaruh positif terhadap loyalitas pada bank syari'ah.Temuan terkahir tanpa dihipotesiskan sebelumnya, budaya (sikap terhadap resiko) memiliki pengaruh terhadap loyalitas pelanggan jasa bank syari'ah. ${ }^{12}$

Banyak faktor yang dapat mempengaruhi nasabah memilih bank syariah, antar lain penelitian yang telah dilakukan oleh Siti Aisyah yang berjudul- hubungan antara citra, fasilitas dan pelayanan terhadap tingkat kepuasan nasabah di perbankan syariah.Hasil penelitian tersebut antara citra, fasilitas, dan pelayanan adalah signifikan terhadap keputusan nasabah. Sehingga ketiga hal tersebut merupakan salah satu yang mempengaruhi nasabah dalam memilih bank syariah. ${ }^{13}$

Samsudin dalam tesisnya yang berjudul "Analisis faktor-faktor mempengaruhi keputusan Nasabah untuk menggunakan jasa Bank Syari'ah Mandiri" (Studi kasus pada nasabah banksyariah mandiri cabang Thamrin). Yang berkesimpulan faktor dominan yangmempengaruhi keputusan nasabah menggunakan jasa Bank Syariah Mandiriternyata

\footnotetext{
${ }^{11}$ Bank Indonesia, Penelitian Potensi, Preferensi dan Perilaku Masyarakat Terhadap Bank Syariah di Wilayah J awa Timu r(Malang :Fak. Ekonomi UNIBRAW,2000).

12 Yudi Sutarso, dkk. "Peranan Penggunaan Prinsip Syari'ah dan Budaya dalam Model Kualitas J asaloyalitas pada Perbankan Syari'ah". Makalah disampaikan pada Forum Riset Perbankan Syaria'ah II 2010, diselenggarakan oleh IPIEF Fakultas Ekonomi UMY, Yogyakarta, 9 desember 2010.

${ }^{13}$ Siti Aisyah, dkk "hubungan antara citra, fasilitas dan pelayanan terhadap tingkat kepuasan nasabah di perbankan syariah" makalah disampaikan pada nasional sistem ekonomi islam IV, diselenggarakan oleh P3EI Fakultas Ekonomi UII, Yogyakarta, 8-9 oktober 2009.
} 
bukan faktor-faktor yang berkaitan dengan artibut syariah Islammelainkan faktor fasilitas dan pelayanan. $^{14}$

Sri Maryati dalam tulisannya yang berjudul Peran Bank Pembiayaan Syariah Dalam Pengembangan UMKM dan Agrisbisnis Pedesaan di Sumatra Barat dalam jurnal Economica menyimpulkan bahwa Berdasarkan karakteristik usaha, pada umumnya nasabah pembiayaan BPRS mempunyai usaha di bidang perdagangan, usaha milik sendiri dengan tempat usaha yang juga milik sendiri dimana mayoritas responden dalam menjalankan usahanya tidak memiliki izin usaha resmi. Pelaku usaha juga harus berusaha mengelola usaha dengan lebih profesional dan memenuhi aspek legalitas usaha agar memudahkan bagi pihak pemerintah maupun lembaga keuangan untuk melakukan berbagai usaha pemberdayaan dan bantuan permodalan. ${ }^{15}$

\section{Landasan Teori}

\section{Produk Pembaiayaan di Bank Syariah}

Pembiayaan merupakan salah satu tugas pokok bank, yaitu pemberian fasilitas penyediaan dana untuk memenuhi kebutuhan pihak-pihak yang merupakan defisit unit. Menurut sifat penggunaannya, pembiayaan dapat dibagi menjadi: ${ }^{16}$

- Pembiayaan konsumtif, yaitu pembiayaan yang digunakan untuk memenuhi kebutuhan konsumsi, yang akan habis digunakan untuk dipakai memenuhi kebutuhan.

- Pembiayaan produktif, yaitu pembiayaan yang ditujukan untuk memenuhi kebutuhan produksi dalam arti luas, yaitu untuk peningkatan usaha, baik usaha produksi, perdagangan, maupun investasi.

Menurut keperluannya, pembiayaan produktif dapat dibagi menjadi;

a. Pembiayaan modal kerja, yaitu pembiayaan untuk memenuhi kebutuhan (1) peningkatan produksi, baik secara kuantitatif, yaitu jumlah hasil produksi, maupun secara kualitatif, yaitu peningkatan kualitas atau mutu hasil produksi; dan (2) untuk keperluan perdagangan atau peningkatan utility of place dari suatu barang.

\footnotetext{
${ }^{14}$ Samsudin, "Analisis faktor-faktor mempengaruhi keputusan Nasabah untuk menggunakan jasa Bank Syariah Mandiri (Studi kasus pada nasabah bank syariah mandiri cabang Thamrin)"Tesis Megister, Jakarta:UI,2004,hal. 156

15 Sri Maryati. Peran Bank Pembiayaan Syariah Dalam Pengembangan UMKM dan Agrisbisnis Pedesaan di Sumatra Barat. Jurnal Economica. Vol.3.No.1 Padang: Prodi Pendidikan Ekonomi STKIP PGRI Padang. 2014., hal 15 ${ }^{16}$ Nur Kholis, Modul Mata Kuliah Manajemen Perbankan Syariah, 2008. Yogyakarta; Prodi Ekonomi Islam Fakultas Agama Islam Universitas Islam Indonesia., hal. 86
} 
b. Pembiayaan investasi, yaitu untuk memenuhi kebutuhan barang-barang modal (capital goods) serta fasilitas-fasilitas yang erat kaitannya dengan itu.

Secara umum jenis-jenis pembiayaan dapat digambarkan sebagai beriku; ${ }^{17}$

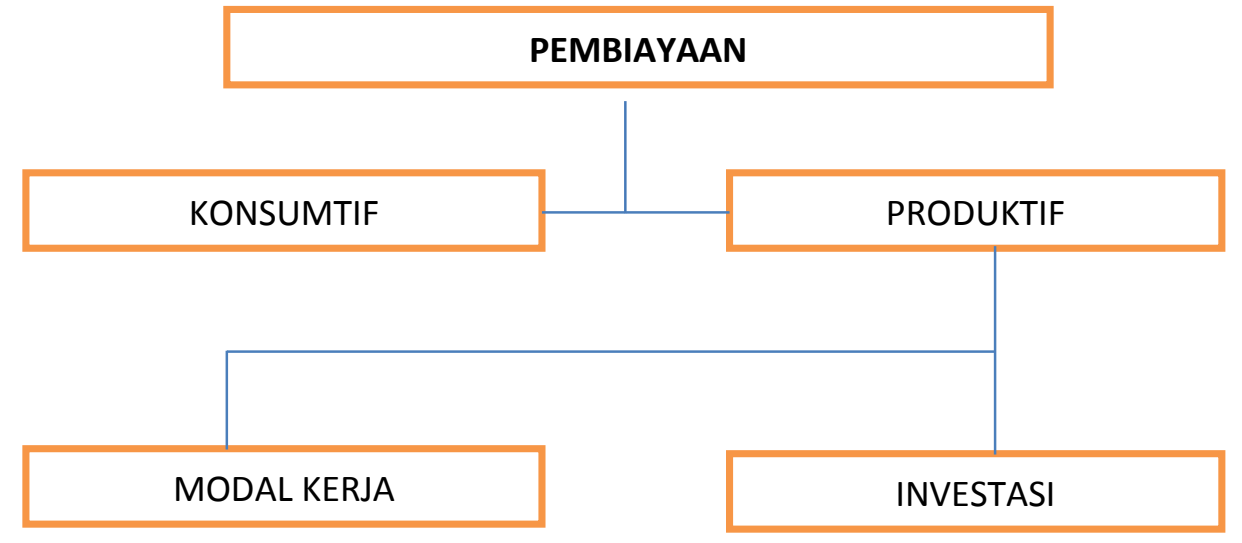

Bank syariah tidak pernah meminjamkan uang tetapi menjual barang kepada nasabah dengan memberikan fasilitas untuk mencicil harga barang. Bank syariah menyewakan barang kepada nasabah untuk jangka waktu tertentu. Untuk memperoleh barang yang dijual atau disewakan kepada nasabah itu, bank syariah membeli dari pemasok barang. Tegasnya, nasabah tidak pernah memperoleh dana berupa pinjaman dari bank syariah. Modus operandi bank syariah yang demikian itu adalah karena bank syariah tidak boleh membebankan bunga kepada nasabah. Artinya, karena berlakunya larangan memberikan pinjaman uang dengan bunga, maka bank syariah tidak memberikan fasilitas pemberiaan dana dengan langsung kepada nasabah seperti halnya bank konvensional, tetapi melalui modus operandi lain. ${ }^{18}$

Kontrak pembiayaan (financing contract) menawarkan jalan untuk menciptakan dan memperluas pembiayaan, memfasilitasi pembiayaan kontrak transaksional, dan memberikan saluran untuk pembentukan kapital dan mobilisasi sumber daya antara investor dan pengusaha. Ciri utama kontrak pembiayaan adalah tidak adanya kontrak utang. Kontrak pembiayaan dimaksudkan untuk pendanaan kontrak transaksional dalam bentuk trade finance (pembiayaan perdagangan) atau asset-backed securities (sekuritas berbasis trade finance ( sekuritas berbasis aset), atau menyediakan modal melalui equity partnership (kemitraan dalam modal) yang dapat diwujudkan dalam beberapa bentuk seperti kemitraan, penyertaan kepemilikan atau kemitraan lainnya. ${ }^{19}$

\footnotetext{
${ }^{17}$ Ibid, hal. 87

${ }^{18}$ Sutan Remy Sjahdaeni, Perbankan Syariah Produk-produk dan Aspek-aspek Hukumnya, 2014. Jakarta: Kencana., hal.176

${ }^{19}$ Muhamad. Manajemen Keuangan Syariah Analisis Fiqih dan Keuangan. 2014. Yogyakarta: UPP STIM YKPN., hal 230 
Pembiayaan berdasarkan prinsip syariah adalah penyediaan uang atau tagihan yang dipersamakan dengan itu berdasarkan persetujuan atau kesepakatan antara bank dengan pihak lain yang mewajibkan pihak yang dibiayai untuk megembalikan uang atau tagihan tersebut setelah jangka waktu tertentu dengan imbalan atau bagi hasil. Prinsip syariah adalah aturan perjanjian berdasarkan hukum islam antara bank dan pihak lain untuk penyimpanan dana dan atau pembiayaan kegiatan usaha, atau kegiatan lainnya yang dinyatakan sesuai dengan syariah, antara lain pembiayaan berdasarkan prinsip hasil (mudharabah), pembiayaan berdasarkan prinsip penyertaan modal (musyarakah), prinsip jual beli barang dengan memperoleh keuntungan (murabahah), atau pembiayaan barang modal berdasarkan prinsip sewa murni tanpa pilihan (ijarah), atau dengan adanya pilihan pemindahan kepemilikan atas barang yang disewa dari pihak bank oleh pihak lain (ijarah wa iqtina). ${ }^{20}$

\section{Perilaku Komsumsi}

Perilaku konsumen terpusat pada cara individu mengambil keputusan untuk memanfaatkan sumber daya mereka yang tersedia (waktu, uang, usaha) guna membeli barang-barang yang berhubungan dengan konsumsi. ${ }^{21}$

\section{a. Menurut Engel Et al (1995)}

Perilaku konsumen adalah tindakan yang langsung terlibat untuk mendapatkan, mengkonsumsi, dan menghabiskan produk dan jasa, termasuk proses keputusan yang mendahului dan mengikuti tindakan ini. ${ }^{22}$

\section{b. Menurut Muhammad Muflih}

Dalam Islam, perilaku seorang konsumen harus mencerminkan hubungan dirinya dengan Allah Swt. Seorang konsumen muslim akan mengalokasikan pendapatannya untuk memenuhi kebutuhan duniawi dan ukhrawinya. Konsumsi tidak dapat dipisahkan dari peranan keimanan. Peranan keimanan menjadi tolak ukur penting karena keimanan memberikan cara pandang dunia yang cendrung mempengaruhi kepribadian manusia, yang dalam bentuk perilaku, gaya hidup, selera, sikap-sikap terhadap sesama manusia, sumber daya, dan ekologi. Keimanan sangat mempengaruhi sifat, kuantitas, dan kualitas konsumsi baik dalam bentuk kepuasan material maupun spiritual. ${ }^{23}$

\footnotetext{
${ }^{20}$ Binti Nur Aisyah. Manajemen Pembiayaan Bank Syariah.2014. Yogyakarta: Teras., hal 2-3

${ }^{21}$ Leon G. Schiffman dkk., Conssumer Behavior, edisi 15, (USA: Prentice Hall International, 1997), hal. 6.

22 James F. Engel dkk., Consumer Behavior, jilid 6, (Jakarta:Binarupa Aksara, 1994.), I: 3.

${ }^{23}$ Muhammad Muflih, Perilaku Konsumen Dalam Perspektif IImu Ekonomi Islam, (Jakarta: PT RajaGrafindo Persada,2006), hal. 4-12.
} 
Batasan konsumsi dalam Islam sebagaimana diurai dalam Alquran surat Al Baqarah : 168169. "Hai manusia, makanlah yang halal lagi baik dari apa yang terdapat dibumi dan janganlah kamu mengikuti langkah-langkah syaitan; karena sesungguhnya syaitan adalah musuh yang nyata bagimu. Sesungguhnya syaitan itu hanya menyuruh kamu berbuat jahat dan keji, dan mengatakan kepada Allah apa yang tidak kamu ketahui. (QS. Al Baqarah: 168169).

Kebutuhan hidup itu harus terpenuhi secara wajar agar kelangsungan hidup berjalan dengan baik. ${ }^{24}$ Difirmankan dalam Alquran surat Al Maidah : 87. "Hai orang-orang yang beriman, janganlah kamu haramkan apa-apayang baik yang telah Allah halalkan bagi kamu, dan janganlah kamumelampaui batas. Sesungguhnya Allah tidak menyukai orang-orangyang melampaui batas. (QS. Al Maidah: 87)

Dari definisi diatas, dapat ditarik beberapa kesimpulan bahwa pengertian perilaku konsumen yaitu:

1) Perilaku konsumen menyoroti perilaku individu dan rumah tangga.

2) Perilaku konsumen menyangkut suatu proses keputusan sebelum pembelian serta tindakan dalam memeperoleh, memakai, mengkonsumsi, dan menghabiskan produk.

3) Mengetahui perilaku konsumen meliputi perilaku yang dapat diamati seperti jumlah yang dibelanjakan, kapan, dengan siapa, oleh siapa dan bagaimana barang yang sudah dibeli dikonsumsi. Juga termasuk variable-variabel yang tidak dapat diamati seperti nilai-nilai yang memiliki konsumen kebutuhan pribadi, persepsi, bagaimana mereka mengevaluasi alternatif, dan apa yang mereka rasakan tentang kepemilikan dan penggunaan produk yang bermacam-macam.

Perilaku konsumen merupakan perkembangan dari psikologi konsumen dalam penelitian yang merupakan perluasan pengambilan keputusan konsumen dalam bidang perilaku ekonomi dan psikologi ekonomi.Dalam bank konsumen disebut dengan nasabah, nasabah adalah setiap orang yang datang ke bank untuk bertransaksi, setiap orang yang ke bank untuk mendapatkan informasi dan setiap orang yang ada di kantor (satu bagian, bagian lain, atau cabang lain). Pepatah mengtakan nasabah adalah raja, maka nasabah wajib dilayanin dengan tulus dan ikhlas. ${ }^{25}$

\footnotetext{
${ }^{24}$ Ibid.Hal 15.

${ }^{25}$ Muhammad, Manajemen Bank Syaraih, (Yogyakarta: AMP YKPN,2005) hal. 225.
} 
Menurut Kasmir, tujuan pemasaran bank secara umum adalah untuk: ${ }^{26}$

a. Memaksimalkan konsumsi atau dengan kata lain memudahkan dan merangsang konsumsi, sehingga dapat menarik nasabah untuk membeli produk yang ditawarkan secara berulangulang

b. Keputusan pembelian dari konsumen sangat dipengaruhi oleh faktor kebudayaan, sosial, pribadi, psikologi dari konsumen. Selain itu, juga di pengaruhi oleh beberapa ransangan pemasaran seperti unsur-unsur di dalam marketing mix dan ransangan lainnya seperti perekonomian, teknologi, politik, dan budaya. Sebagian besar adalah faktor-faktor yang tidak dapat dikendalikan oleh pemasar, tetapi harus benar-benar diperhitungkan.

Proses pengambilan keputusan dapat di pandang sebagai tiga tahap yang berbeda namun berhungan satu sama lain dipaparkan Leon schiffman dkk dalam bukunya yang berjudul perilaku konsumen. Tahap masukan mempengaruhi pengenalan konsumen melalui sumber informasi utama: usaha pemasaran perusahaan (produk itu sendiri, harganya, promosinya, dan di mana ia dijual). Tahap proses model memfokuskan berbagai faktor psikologis yang melekat pada individu (motivasi, persepsi, pengetahuan, kepribadian, dan sikap). Tahap keluaran kegiatan setelah pengambilan keputusan yang berhubungan erat: perilaku membeli dan evaluasi setelah membeli. ${ }^{27}$

Perilaku konsumsi seperti ini tentunya tidak dapat diterima begitu saja dalam konsep ekonomi islam. Konsumsi yang islami selalu berpedoman dengan ajaran islam. Di antara ajaran yang penting berkaitan dengan konsumsi, misalnya perlu memperhatikan orang lain. Hal lain adalah tujuan konsumsi itu sendiri di mana seorang muslim akan lebih mempertimbangkan mashlahah daripada utilitas. Pencapaian mashlahah merupakan tujuan dari islam (maqasid syariah), yang tentu saja harus menjadi tujuan dari kegiatan konsumsi. ${ }^{28}$

Perbedaan karakteristik manusia dalam berfikir, berkata, dan bertindak. Seseorang akan dikatakan baik bila perilakunya sesuai dengan ajaran agama, dan sebaliknya akan buruk bila perilakunya tidak sesuai dengan ajaran agama. Proses dari berfikir hingga bertindak sesuai dengan ajaran agama tentu erat kaitannya dengan kendali unsur-unsur manusia yang memiliki seseorang. ${ }^{29}$ Persepsi adalah peroses yang digunakan oleh individu untuk memilih,

\footnotetext{
${ }^{26}$ Setiadi, "Perilaku Konsumen: Konsep dan Implikasi untuk Strategi dan Penelitian Pemasaran". (Jakarta: Prenada Media, 2005)Hal.11. ${ }^{27}$ Leon G. Schiffman dkk, Perilaku Konsumen, Bambang Sarwiji (ed.), Cet. IV, (ttp.: PT Macanan Jaya Cemerlang, 2008, 7), hal 7-8. ${ }^{28}$ Pusat Pengkajian dan Pengembangan Ekonomi Islam (P3EI) UII, Ekonomi Islam, (Jakarta: PT. Raja Grafindo Persada, 2008),. hal.128. ${ }^{29}$ Muhammad Muflih, Perilaku Konsumen........, hal. 51.
} 
mengorganisasi, dan menginterprensi masukan informasi guna menciptakan gambaran dunia yang memiliki arti. ${ }^{30}$

Persepsi konsumen berkaitan erat dengan kesadarannya yang subyektif mengenai realitas sehingga apa yang dilakukan seorang konsumen merupakan reaksi terhadap persepsi subyektifnya, bukan berdasar pada realita yang objektif. Jika seorang konsumen berfikir mengenai realitas, itu bukanlah realitas yang sebenarnya, tetapi merupakan pikirannya mengenai realitas yang akan mempengaruhi tindakannya, seperti keputusan membeli sesuatu. $^{31}$

Perintah-perintah Islam terhadap perilaku konsumsi dituntun oleh lima prinsip, yaitu : ${ }^{32}$

1. Prinsip Keadilan

2. Prinsip Kebersihan

3. Prinsip Kesederhanaan

4. Prinsip Kemurahan Hati

5. Prinsip Moralitas.

Kunci untuk memahami perilaku konsumen dalam Islam tidak terletak dengan hanya mengetahui hal-hal yang terlarang tetapi juga dengan menyadari konsep dinamika tentang sikap moderat dalam konsumsi yang dituntun oleh perilaku yang mengutamakan kepentinga orang lain, yaitu seorang konsumen muslim. Larangan-larangan Islam mengenai makanan dan minuman harus dipandang sebagai usaha untuk memperbaiki perilaku konsumen. ${ }^{33}$

\section{Metode Penelitian}

\section{Jenis Penelitian}

Jenis penelitian yang digunakan dalam tulisan ini adalah dengan menggunakan studi pustakayang diperoleh dari beberapa sumber. Yang menjadi sumber utama dalam tulisan ini adalah buku yang ditulis oleh Eko Widiyanto, yang berjudul Dengan Keluarga Sakinah Membangun Bisnis Barokah. Yogyakarta: Mitra Pustaka Nurani. Didalamnya menjabarkan tentang pengalaman penusaha Pamella Sunardi dalam mengembangkan bisnisnya kemudian menerapkan etika bisnis Islam, kemudian menguraikan keputusannya memilih bank syariah.

\section{Sifat Penelitian}

\footnotetext{
${ }^{30}$ Philip Kolter, Manajemen Pemasaran, Benyamin Molan (ed.), Cet. III, (ttp.: PT Macanan Jaya Cemerlang, 2008, 7), hal 228.

${ }^{31}$ Ibid. hal. 91-92

${ }^{32}$ Abdul Mannan, Teori dan Praktek E konomi Islam, ( Yogyakarta: PT. Dana Bhakti Wakaf, 1997), hal.45.

33|bid, hal. 51
} 
Penelitian ini bersifat deskriptif kualitatif yang artinya menggambarkan suatu subyek penelitian. Dalam hal ini adalah kondisi jumlah nasabah di bank syari'ah. Kemudian tentangketertarikan pengusaha muslim Pamella Sunardi pemilik supermarket Pamella Yogyakarta menggunakan produk pembiayaan di bank syariah.

\section{Jenis Data}

Jenis data yang digunakan dalam tulisan ini adalah data kualitatif yang bersumber dari data primer dan data sekunder. Data primer berupa sumber data yang langsung memberikan data kepada peneliti atau data yang diperoleh langsung dari lapangan (objek penelitian), sedangkan data sekunder adalah sumber data yang tidak langsung memberikan data kepada pengumpul data (peneliti) atau data yang diambil peneliti sebagai pendukung atas penelitian secara ilmiah yaitu dengan melakukan studi pustaka (penelusuran melalui buku, artikel, jurnal, majalah, internet dan sumber lainnya). ${ }^{34}$

Data-data yang digunakan penulis antara lain:

1. Teori-teori yang peneliti ambil dari berbagai literatur.

2. Pengambilan data-data dari hasil yang telah tersaji dari suatu lembaga.

\section{Batasan Penelitian}

Batasan dalam tulisan ini difokuskan pada produk pembiayaan di bank syari'ah. Serta tentang ketertarikan pengusaha muslim Pamella Suanrdi pemilik supermarket Yogyakarta menggunakan produk pembiayaan di bank syariah. Dengan mengamati buku biografi yang menciratakan kisah hidup ataou perjalan hidup Pamella Sunardi. Batasan dalam tulisan ini juga pada kondisi faktual dari produk deposito di bank syari'ah, yang terjadi pada bank syari'ah saat ini yang market sharenya baru mencapai $5 \%$ apabila dibandingkan perbankan secara nasional.

\section{Teknik Pengumpulan Data}

Teknik pengumpulan data yang diperlukan dalam tulisan ini adalah dengan menggunakan beberapa metode yaitu:

\footnotetext{
${ }^{34}$ Farizal.Pengembangan Kompetensi SDM Perbankan Syariah Melalui Corporate University. Forum Riset Perbankan Syariah II. 2010. Yogyakarta. Hal 66 
Studi Kepustakaan. Metode ini digunakan untuk menggali dasar-dasar teori yang terkait produk pembiayaan di bank syariah dan teori yang terkait dengan pola perilaku konsumen dalam memilih suatu produk/ barang.

Pengamatan. Setiap data yang didapatkan dari berbagai sumber diamati dan dianalisa terkait dengan kondisi jumlah nasabah produk pembiayaan di bank bank syariah. Kemudian diuraikan keputusan Pamella Sunardi memilih bank syariah. Yang diamati bukan hanya keputusan atau ketertarikan Pamella Sunardi menggunakan bank syariah secara normatif, tetapi juga data yang diperoleh dari statistik perbankan syariah yang dikeluarkan oleh Otoritas Jasa Keuangan (OJK).

\section{Analisis data}

Metode analisis data yang digunakan adalah dengan menggunakan pendekatan kualitatif deskriptif yaitu dengan cara memaparkan metode teori produk pembiayaan di bank syari'ah, kemudian teori perilaku konsumsi terhadap potensi pengembangan produk pembiayaan di bank syariah.

Penelitian kualitatif adalah prosedur penelitian yang menghasilkan data deskriptif berupa kata-kata tertulis atau lisan dari orang-orang dan keadaan yang diamati. Penelitian kualitatif adalah metode penelitian yang digunakan untuk meneliti pada kondisi objek yang alamiah, (sebagai lawannya adalah eksprimen) dimana peneliti adalah sebagai instrument kunci, teknik pengumpulan data dilakukan secara trianggulasi (gabungan), analisa data bersifat induktif dan hasil dari penelitian kualitatif lebih bersifat makna daripada generalisasi. ${ }^{35}$

\section{Pembahasan}

Ketertarikan Pengusaha Muslim Pamella Sunardi Pemilik Supermarket Pamella Yogyakarta menggunakan produk pembiayaan di bank syariah.

Sosok Pamella Sunardi pemilik supermarket Pamella Yogyakarta adalah sosok yang terkenal religius, banyak paham akan ilmu agama. Hal ini tidak lepas dari bimbingan sang suami yang seorang guru agama dan juga banyak melibatkan dalam kegiatan/ organisasi keagamaan. Dalam mengembangkan usaha supermarket Pamella Sunardi menerapkan etika bisnis islam. Saat ini, jumlah karyawan yang bekerja di Pamella group, mencapai sekitar 600 orang. Sebagian besar karyawan adalah wanita, karena jenis pekerjaan di supermarket memang lebih cocok dikerjakan kaum wanita. Untuk menciptakan suasana yang islami, pada setiap karyawati kami wajibkan mengenakan pakaian muslimah. Ketentuan ini juga berlaku

${ }^{35}$ lbid, hal 67 
bagi para SPG (Sales Promotion Girl) yang dipekerjakan pihak supplier untuk melakukan promosi di supermarket kami. Dalam hal melakukan ibadah, kami juga memberi kesempakatan kepada karyawan untuk melaksanakan shalat lima waktu. Agar bisa melaksanakan shalat tanpa harus mengabaikan layanan terhadap konsumen, maka mereka dibagi dalam beberapa shift. Demikian juga pada bulan ramadhan, mereka kami beri kesempatan untuk berbuka dengan cara bergantian; ungkap Pamella Sunardi. ${ }^{36}$ Selanjutnya, penerapan etika bisnis islam terlihat pada kepedulian terhadap masyarakat yang tidak mampu dengan melakukan kegiatan sosial. Berkaca pada pengalaman yang lalu, maka sejak usaha ritel kami masih dalam skala kecil, maka kami membiarkan diri untuk menyisihkan zakat. Dana yang terkumpul itu kami salurkan kepada keluarga-keluarga tidak mampu di sekitar Pamella. Namun setelah usaha kami besar dan zakat yang diperoleh juga semakin besar, saya menjalin kerjasama dengan pihak lain, antara lain dengan Rumah Zakat (RZ), Dompet Dhuafa (DD), PKPU, DPU DT dan lembaga sosial lainnya. Melalui berbagai lembaga inilah, kami mengadakan kegiatan-kegiatan sosial seperti program pembagian sembako, pengobatan gratis atau kegiatan donor darah yang dilakukan bekerjasama PMI. ${ }^{37}$

Pengalaman Pahit dengan Bank konvensional menjadikan Pamella Sunardi trauma dengan bank, sehingga pada akhirnya memilih pembiayaan di Bank syariah salah satu alasan Hampir semua modal usaha Ayahnya berasal dari pinjaman bank, dan dengan itu berbagai macam usahapun terus maju dan bekembang. Pada tahun 1970, Ayahnya jatuh sakit sampai akhirnya meninggal dunia dan semua usaha yang dirintis selama itu mengalami kerugian sehingga akhirnya menjadi hancur dan berantakan dikarenakan tidak ada yang mengelola. Singkat cerita Noor Liesnani dan Ibunya harus berjuang sekuat tenaga untuk melunasi semua hutang kepada bank yang dirasa sangat memberatkan. Dengan adanya kejadian tersebut, seorang Noor Liesnani yang pada waktu itu berusia 15 (lima belas) tahun dan sedang duduk di bangku SMP berpendapat bahwa bekerja dengan modal pinjaman dari bank itu sangat menakutkan bahkan dia sampai mempunyai anggapan miring bahwa bank itu jahat. Oleh karena itu dia pernah berjanji dengan ungkapan "Apabila besok saya bekerja, tidak akan meminjam modal dari bank". Secara kebetulan, suaminya Sunardi Syahuri yang notabene seorang Mubaligh berpendapat bahwa bunga bank itu haram hukumnya, maka jadilah usaha mereka yaitu Warung Pamella dalam hal permodalan tanpa menggunakan kredit bank. ${ }^{38}$ Kemudian pada keputusan memilih bank syariah.

Pamella Sunardi kemudian mengembangkan bisnis dengan mendirikan bisnis SPBU. Menurutnya, proses untuk mendirikan SPBU itu bukan hal mudah. Kami membutuhkan waktu hampir dua tahun untuk menyelesaikan seluruh proses perizinan hingga akhirnya SPBU tersebut dapat beroperasi. SPBU itu di berinama SPBU Pamella yang secara resmi beroperasi pada tahun november 2005. Lebih lanjut dia mengungkapkan untuk terjun ke bisnis SPBU, dirinya membutuhkan dana yang cukup besar. Bila hanya mengandalkan dana tunai yang kami miliki sendiri, tidak akan mencukupi. Kami akhirnya memutuskan mengambil mengambil kredit/ pembiayaan dari Bank BRI Syariah. Sedangkan

\footnotetext{
${ }^{36}$ Eko Widiyanto, Dengan Keluarga ,hal., 181

${ }^{37}$ |bid, hal. 186-187

${ }^{38}$ Dikutip dari http://pamellagroup.blogspot.co.id/2009/12/sejarah.htmlpada tanggal 12 Oktober 2016
}

64 | al-Maslahah-Volume 13 Nomor 1 April 2017 
pengembaliannya, diangsur selama lima tahun. Saat ini, seluruh hutang untuk modal mendirikan SPBU sudah lunas. Bahkan kami bisa membeli lahan di sekitar SPBU. Sehingga areal pengisian bahan bakar bagi kendaraan menjadi lebih luas. Bahkan kami juga bisa mendirikan oulet Pamella delapan di kompleks SPBU. ${ }^{39}$

Kalangan perbankan syariah memperkirakan, pada 10 tahun yang akan datang pangsa pasar perbankan syariah akan meningkat menjadi 15\%-20\%. Porsi pasar ini tentu akan memberi tantangan bagi pelaku perbankan syariah sebab hal itu akan membutuhkan tenaga yang tidak kecil. Apalagi, selama 10 tahun terakhir porsi pasarnya sulit mencapai 5\%. Tidak hanya itu, meskipun mayoritas penduduk Indonesia ialah muslim, hal itu ternyata tidak secara langsung bisa membuat porsi pasar perbankan syariah meningkat tajam. Bahkan, secara keseluruhan di dunia, menurut survei World Bank, orang menggunakan jasa keuangan syariah tidak segaris lurus dengan sentimen keagamaan. Hanya 30\% yang memilih bank syariah berdasarkan sentimen agama. ${ }^{40}$ Pamella Sunardi menjadi yang termasuk memilih produk pembiayaan bank syariah karena alasan ketaatan pada agama. Kemdian dengan faktor lainnya.

\section{Simpulan}

Ketertarikan pengusaha muslim Pamella Sunardi pemilik supermarket menggunakan produk pembiayaan di bank syariah, tidak lepas dari pola hidup yang dijalani yang lekat dengan agama. Pamella sunardi menerapkan etika bisnis islam dalam menjalankan usaha mini market yang dimilikinya. Kemudian Pamella sunardi memiliki pengalaman yang buruk saat menggunakan jasa di bank konvensional. Dirinya sempat trauma menggunakan jasa perbankan konvensional, sehingga pada saat ingin mengembangkan usaha awalnya enggan menggunakan jasa perbankan. Sehingga pada waktu membuka usaha SPBU yang membutuhkan dana yang cukup besar, membuat Pamella Sunardi kembali menggunakan jasa perbankan syariah dengan mengajukan pembiayaan di Bank BRI Syariah.

\section{DAFTAR PUSTAKA}

Al-Qur'anul Karim

Aisyah Siti, dkk. Hubungan antara Citra, Fasilitas dan Pelayanan terhadap tingkat Kepuasan Nasabah di Perbankan Syariah. Makalah disampaikan pada nasional sistem ekonomi islam IV, diselenggarakan oleh P3EI Fakultas Ekonomi UII, Yogyakarta, 8-9 oktober 2009.

Antonio, Muhammad Syafii. 2000. Bank Islam: Teori dan Praktek. Jakarta: Gema Insani Press.

Algaoud Latifa M. dan Mervyn K. Lewis. 2001. Perbankan Syariah, Prinsip, Praktik, Prospek, Jakarta: PT. Serambi Ilmu Semesta.

Alwi, Syafaruddin. 2013. Memahami Sistem Perbankan Syariah. Jakarta BukuRepublika. 
Bank Indonesia., Pusat Pengajian Bisnis, dan Ekonomi Islam Fak. Ekonomi UNIBRAW. 2000. Potensi, Preferensi dan Perilaku Masyarakat terhadap BankSyariah di Jawa Timur. Malang: Ekcekutive Summary Hasil Penelitian.

Bank Indonesia., 2000. Potensi, Preferensi dan Perilaku Masyarakat terhadap Bank Syariah di Jawa Barat. Bogor: Lembaga Penelitian IPB.

Engel, James F. dkk. 1994. Consumer Behavior, jilid 6, Jakarta:Binarupa Aksara.

Farizal. 2010. Pengembangan Kompetensi SDM Perbankan Syari'ah Melalui Corporate University, Forum Riset Perbankan Syariah II, Yogyakarta.

Kholis,Nur.2008. Modul Mata Kuliah Manajemen Perbankan Syariah. Yogyakarta; Prodi Ekonomi Islam Fakultas Agama Islam Universitas Islam Indonesia.

Kolter, Philip. 2008.Manajemen Pemasaran, Benyamin Molan (ed.), Cet. III, (ttp.: PT Macanan Jaya Cemerlang.

L. Loudon, dkk. 1998. Consumer Behavior, jilid 3. New York : Mc Graw-Hill Book Company.

Mannan, Abdul. 1997. Teori dan Praktek Ekonomi Islam.Yogyakarta: PT. Dana Bhakti Wakaf.

Maryati, Sri. 2014.Peran Bank Pembiayaan Syariah Dalam Pengembangan UMKM dan Agrisbisnis Pedesaan di Sumatra Barat. Jurnal Economica. Vol.3.No.1 Padang: Prodi Pendidikan Ekonomi STKIP PGRI Padang.

Muhammad. 2005. Manajemen Bank Syariah. Yogyakarta: AMP YKPN.

Muhamad. 2014. Manajemen Keuangan Syariah Analisis Fiqih dan Keuangan. Yogyakarta: UPP STIM YKPN.

Muflih, Muhammad. 2006. Perilaku Konsumen Dalam Perspektif Ilmu Ekonomi Islam.Jakarta: PT Raja Grafindo Persada.

Nur, Binti Aisyah. 2014. Manajemen Pembiayaan Bank Syariah. Yogyakarta: Teras.

Otoritas Jasa Keuangan. 2016. Statistik Perbankan Syari'ah.

Pusat Pengkajian dan Pengembangan Ekonomi Islam (P3EI) UII. 2008. Ekonomi Islam. Jakarta: PT. Raja Grafindo Persada.

Remy, Sutan Sjahdeini. 2014. Perbankan Syariah Produk-produk dan Aspek-aspek Hukumnya. Jakarta: Kencana. 2014.

Samsudin. 2004. Analisis faktor-faktor mempengaruhi keputusan Nasabah untuk menggunakan jasa Bank Syariah Mandiri (Studi kasus pada nasabah bank syariah mandiri cabang Thamrin). Tesis Megister. Jakarta:UI.

Setiadi, Nugroho J. 2005. Perilaku Konsumen: Konsep dan Implikasi untuk Strategi dan Penelitian Pemasaran. Jakarta: Prenada Media.

Schiffman, Leon G dan Kanul Leslie Lazar. 2008. Consumre Behaviour. Bambang Sarwiji (terj.), Perilaku Konsumen. Indonesia: PT Macanan Jaya Cemerlang.

Tjiptono, Fandi .2002. Pemasaran Jasa. Malang: Bayu Media.

Widiyanto, Eko. 2013. Dengan Keluarga Sakinah Membangun Bisnis Barokah. Yogyakarta: Mitra Pustaka Nurani.

Yudi, Sutarso, dkk. Peranan Penggunaan Prinsip Syari'ah dan Budaya dalam Model Kualitas J asaloyalitas pada Perbankan Syari'ah. Makalah disampaikan pada Forum Riset Perbankan Syaria'ah II 2010, diselenggarakan oleh IPIEF Fakultas Ekonomi UMY, Yogyakarta, 9 desember 2010.

http://www.bi.go.id/web/id/Perbankan/Perbankan+Syariah/Pada tanggal 18 pebruari 2011 http://pamellagroup.blogspot.co.id/2009/12/sejarah.html pada tanggal 12 Oktober 2016 http://www.republika.co.id/berita/ekonomi/syariah-ekonomi/14/04/21/n4dbe9-ojk-indonesiabutuh-bank-syariah Pada Tanggal 10 Januari 2017.

http://infobanknews.com/keuangan-syariah-yang-belum-rasional/ pada tanggal 10 Januari 2017 